\title{
Cerzido invisível - Sobre um modo de reconstituição do texto poético
}

ALÍPIO CORREIA DE FrANCA NETO

$\mathrm{N}$ O COMEÇO foram os poetas concretistas e, por meio deles, Ezra Pound. Quem quer que traduza poesia e pertença à minha geração dificilmente terá escapado à sua influência. Traduções como "O navegante”, "Ode a um rouxinol”, "Bizâncio”, de Augusto de Campos, ou mesmo os Cantos do "Paraíso" de Dante traduzidos por Haroldo de Campos, dentre outros exemplos, continuam, por motivos variados, a me servir de modelos de traduções poéticas.

Depois que eu mesmo já havia acumulado experiência como praticante dessa modalidade literária, por vezes me via forçado a divergir de uma ou outra estratégia ${ }^{1}$ adotada em traduções poéticas por esses mestres ou adeptos confessos de ideias poundianas, quando não dos argumentos que as justificavam. Se a tradução poética era norteada pela crítica - o que é absolutamente assente -, algumas liberdades semânticas em produções creditadas a essa linha me soavam, por assim dizer, verdadeiras "superinterpretações". Quanto a Pound, com o correr do tempo, passei a voltar os olhos às suas versões e a concordar com ele sobre o que elas de fato eram - extensões de sua obra poética original, ${ }^{2}$ que acabaram por influenciar profundamente a poesia do século XX. Não eram o que eu pudesse entender por "traduções", e sim o que depois se chamaria de "apropriações", aspecto que pode ter dado a razão de esses poemas sempre terem sido aprovados unanimemente por juízes em poesia e ao mesmo tempo terem sido motivo de controvérsias com filólogos. Quanto a meu compromisso com tradução poética, contudo, o que está implicado nesse ponto de vista pessoal é que, até meados dos anos 1990, minhas preocupações sobre o assunto giravam em torno de quais características nessa modalidade literária teriam o condão de fazer dela uma "tradução" e ao mesmo tempo um "poema”. Por essa época, é possível que eu tivesse certa ideia vaga do que não fazer numa tradução poética, embora não tivesse muitas conviç̧ões sobre como proceder para que meus esforços resultassem nela.

Acho que as coisas começaram a mudar nos primeiros anos da virada do século, quando me vi na contingência de tratar do assunto em sala de aula e de ter um contato mais aprofundado com a obra de Michael Hamburger (19242007). 
Hamburger não deixou propriamente uma teoria da tradução, mas foi autor de um número considerável de escritos críticos e declarações públicas sobre tradução de poesia, a reboque de uma monumental obra tradutória, ${ }^{3}$ que na Europa e nos Estados Unidos têm sido considerados um contraponto a ideias poundianas, ou mesmo uma alternativa a estratégias encontradiças em seus adeptos. Na verdade, seu trabalho nessa área tem servido de referência a diversos tradutores europeus de prestígio, ${ }^{4}$ e, grosso modo, se caracteriza por uma abordagem que deliberadamente se afasta de algumas técnicas poundianas, questionando-lhes e rejeitando as liberdades semânticas, sem descurar em momento algum do objetivo de poeticidade nos textos.

Meu contato com a obra desse tríplice talento de poeta, crítico e tradutor se estreitou a partir de 2002 quando, convicto da importância de difundir suas ideias por aqui, resolvi traduzir por conta própria seu estudo seminal sobre poesia moderna, $A$ verdade da poesia, posteriormente aceito e publicado por uma editora brasileira. Foi durante esse período que tive a oportunidade de me corresponder com ele a propósito de dificuldades dessa tradução, e de em uma ocasião contar com seus comentários acerca de uma versão que fiz de um poema de Philip Larkin, ${ }^{5}$ de quem Hamburger foi amigo. Minha identificação com suas ideias sobre tradução poética foi de tal ordem, que comecei a rastreá-las em outras obras de sua autoria. Lembro que as palavras que se seguem, bastante despretensiosas por sinal, tiveram impacto sobre mim na época em que foram lidas. Devo fazer uma citação de peso:

De tempos em tempos, sou requisitado a escrever sobre os "problemas da tradução de poesia". Diversas vezes descubro que esses problemas me aborrecem, como a atividade não o faz. Se eu cumpro com a solicitação, mais cedo ou mais tarde me vejo utilizando de maneira diferente a divisão que Dryden levou a cabo acerca da tradução poética em três tipos - metáfrase, paráfrase e imitação - e afirmando que, mutatis mutandis, ela é tão válida hoje quanto foi quando ele a criou. Ao mesmo tempo, me pego aborrecido com o conhecimento de que, além dessa útil distinção, há regiões de especulação e analogia que poderiam ser metafísicas, antropológicas ou estéticas; de que, na prática, as três categorias de Dryden tendem a se imbricar; e que hoje dispomos de modos de análise científica, ou quase-científica, da linguagem, do significado e da interpretação, dos quais todos sugerem que a tradução é uma impossibilidade. [...] Se eu reflito sobre algo não é sobre problemas, que são a província dos teóricos, mas sobre dilemas, sobre fracassos específicos ou completos ou parciais. Estes podem ser explicados, embora nenhuma quantidade de explanação venha a me ajudar a traduzir o que, para mim, é intraduzível. [...] E uma conclusão a ser tirada... é que a poesia não é necessariamente mais intraduzível do que qualquer outro tipo de escrita. Uma grande quantidade de poemas líricos pode ser mais difícil de "entender"; porém, quanto mais difícil o poema, mais complexa e idiossincrática a sua estrutura, mais provável é que uma boa quantidade de sua "quididade" seja transmitida satisfatoriamente na tradução. É o poema mais singelo, mais límpido, que pode desafiar a tradução, porque ele deixa a menor latitude para a paráfrase e a interpretação, e a singeleza que pode 
ser uma feliz redução numa língua e uma convenção literária pode soar como uma banalidade intolerável em outra. $\mathrm{O}$ tipo de tradução que pratico requer de mim que eu entenda um poema, tanto quanto ele possa ser compreendido, ao passo que um bom número de imitadores prefere não se ver constrangido por essa exigência, o que lhes restringiria a liberdade. [...] Questões lingüísticas, semânticas e hermenêuticas sobre a possibilidade da tradução numa língua do que foi escrito em outra tendem a favorecer a liberdade da imitação. Se a tradução não produz um verdadeiro equivalente, reza o argumento, um tradutor de poesia pode igualmente desistir da tentativa de o produzir. Muito melhor para ele é fazer o que é dele, escrever um novo poema na sua própria língua, a sua própria maneira, usando o original para seus próprios fins “criativos". Não tenho divergências quanto a esse procedimento, mas acredito que haja um ponto em que ele deixa de ser uma tradução e não pode ser julgado como tal. As variações sobre um tema, na música, são julgadas como obras originais, independentemente de se o tema é tomado ou não de outro escritor. A tradução, do modo pelo qual a entendo, está muito mais próxima de uma transcrição, rearranjo ou re-instrumentalização da obra de um outro compositor, tal como as que Bach fez de Vivaldi. Por muito que livres, tais transcrições continuam a ser interpretações da obra transcrita, e as liberdades tomadas servem para transportar a obra a uma outra convenção, uma outra época, não para desmanchá-la a fim de que nos apropriemos de uma parte promissora. [...] A apropriação, é claro, pode ser esteticamente mais produtiva do que se pode fazer no modo da tradução; mas isso é um sacrifício que um tradutor deve à obra traduzida. Qualquer poeta capaz de ler traduções de sua própria obra é passível de preferir uma versão cuidadosa, embora imperfeita, do que ele escreveu a um exercício de apropriação, se o resultado for apresentado como uma versão de seu texto, não como uma variação em torno dele. Isso não é uma reivindicação da metáfrase, ou tradução pedantemente literal. [...] A fidelidade ao texto traduzido pode demandar um grau considerável de liberdade no nível semântico - exatamente quanto, isso variará de autor a autor, de texto a texto, de língua a língua, de período a período. Toda tradução, distinta de uma apropriação, reclama um ato de compreensão que é também uma avaliação do que constitui o gesto primário de um poema e um juízo de como esse gesto pode ser reencenado em outro meio [...] Versões do tipo que produzo, evidentemente, serão de validade limitada, porque não visam a substituir os textos originais, mas a transmitir tanto de sua quididade quanto sou apto a transmitir, e a fazê-lo de maneira tanto mais efetiva quanto poderia ser feito por meio da descrição ou análise. ${ }^{6}$

Cito essas palavras porque, vejo agora, elas verbalizavam o que até então me eram apenas intuições, além de terem contribuído para que eu tentasse posteriormente usar de procedimentos específicos, suponho, de maneira mais coerente e consecutiva. A essa altura a mim também só me interessavam "dilemas", não "problemas" tradutórios. Por outro lado, embora a tradução seja um empreendimento pragmático, é impossível realizar a tarefa sem referência a uma teoria ou teorias sobre ela, de modo que, às voltas com a tradução de poesia eu também me pegava recorrendo à antiga classificação de Dryden, mesmo que ela merecesse reparos ou talvez fosse passível de comportar subdivisões. Além disso, 
eu concordava com Hamburger sobre o fato de a crença a priori na intraduzibilidade da poesia, às vezes implícita, às vezes alardeada, dar a razão de eventuais liberdades semânticas, de se tender à "imitação", conforme Dryden e Hamburger entendiam essa palavra, ou seja, sem nenhum juizo de valor negativo. Ao contrário, como ele diz, a esses mesmos "imitadores" podia ocorrer contribuírem com obras capazes de se incorporar à literatura do país em que se originavam. Além do mais, jamais se pode menosprezar o valor da "imitação", visto que é a forma mais antiga e importante dessa modalidade literária. A imitação nunca desapareceu de todo, mesmo depois da desaprovação de Dryden, o trabalho assombroso do próprio Pound na época moderna sendo a maior evidência disso. ${ }^{7}$ Hamburger tem consciência dessa importância, e a esse tipo de composição, capaz de "desmanchar" uma obra para selecionar sua parte "mais promissora", estabelecendo com ela um diálogo livre, ele preferia chamar de "apropriação". Essa distinção sempre me pareceu útil ${ }^{8}$ bem como a que há entre a ideia da relação entre crítica e tradução para Pound e Hamburger. Para os dois, a crítica constitui a força motriz e norteadora do processo, mas, para o primeiro, a partir de determinado momento do processo de tradução, essa força pode se ocupar daquele trabalho de "seleção", ou da detecção daquela parte "promissora" e, conforme seus objetivos, se entregar ao jogo livre da "criação", ao passo que Hamburger vê o resultado final do trabalho de se traduzir um poema como levando a efeito o que se pode chamar de uma "crítica em verso", ou em forma de um poema cujas estruturas equivalentes, ou isomorfas, a depender do talento individual, da organização e recursos de uma língua, se plasmaram, gesto por gesto, a partir de um processo de interpretação.

Não posso pensar na intraduzibilidade da poesia a priori, já que a contínua prática de tradução poética ao longo dos tempos sempre a desmentiu. O Finnegans wake e muitos poemas de Celan, por exemplo, ao levar a linguagem ao limite do "dizível" ou "traduzível", só fizeram, e fazem, incitar e justificar novas versões. Desse ângulo, mesmo no caso de textos que apresentem uma diç̧ão social ou histórica sem uma contraparte em nossa língua, nada impede que um tradutor, utilizando coloquialismos, regionalismos, neologismos ou coisa que o valha possa "traduzir" aspectos da "quididade" desse texto. A experiência comum ensina que aquilo que a princípio parece intraduzível pode não se mostrar assim posteriormente, a depender das mudanças de nossa leitura. Muito tempo depois de considerarmos solidificado o ferro que fundimos, ele ainda poderá aceitar outra forma. Ao deparar, por exemplo, num romance, com as seguintes notas de pé de página, "No original, trocadilho intraduzível entre...", ou, "diante da impossibilidade de tradução, optei por...", sempre considero impróprias as formulações, justamente por ter visto diversas delas ser desmentidas por soluções aceitáveis de outros tradutores. Esse aspecto faz a "intraduzibilidade" depender do talento individual e da questão extraliterária e prosaica da falta de tempo, já que essa é uma atividade que a rigor não deveria ter prazo para terminar. 
Aos que creem no caráter traduzível da maior parte da quididade do poema, não resta senão ter a esperança da expressão, já que a crença na intraduzibilidade ou ameaça com o silêncio ou com uma forma de expressão que nos levará para além de uma tradução, como a imitação. Por muito tempo, achei que jamais encontraria a palavra "certa" para a tradução deste poema de Stephen Spender, por sinal, o primeiro que traduzi na vida:

The word bites like a fish.

Shall I throw it back free

Arrowing to that sea

Where thoughts lash tail and fin?

Or shall I pull it in

To rhyme upon a dish??

Numa ocasião, porém, lendo Clarice Lispector ("Então escrever é o modo de quem tem a palavra como isca: a palavra pescando o que não é palavra. Quando essa não palavra morde a isca, alguma coisa se escreveu"), tive a impressão de que alguma coisa "mordera a isca", e cheguei a isto:

Palavra é peixe e belisca.

Devolvo-a livre a esse oceano,

Lançando aonde ideias abanam

A barbatana e a cauda?

Ou a coloco no final da

Linha pra rimar com isca? ${ }^{10}$

Por sua vez, no que tange ao que é mais "difícil" traduzir quando nos propomos a fazer paráfrases, constatamos a verdade das palavras de Hamburger sobre o fato de o poema de estrutura mais complexa e idiossincrática ser o mais passível de ter sua "quididade" transplantada, ou, o que dá no mesmo, sobre o poema mais "singelo" ser o mais refratário à tradução, por não permitir margem de manobra às operações da paráfrase. ${ }^{11}$ Isso dá a razão de esse poema de Spender que acabo de citar, dos poemas de Música de câmara e da Balada do velho marinheiro terem me parecido tão refratários à tradução.

Até agora me referi à paráfrase de maneira um tanto vaga, com receio de estar dando a entender que disponho de um "método" de uso pessoal para a tradução do poema. Como disse Wittgenstein, não pode haver um método sistemático para isso e, a meu ver, tal impossibilidade advém do fato de a atividade requerer a, um só tempo, capacidade de escrita e de interpretação, o que varia de pessoa a pessoa. Para o tipo de tradução que procuro fazer, gosto de pensar que a atividade também requer certa dose de "capacidade negativa", a qual, para Keats, caracterizava a natureza poética, ou o "poeta-camaleão", facultando-lhe se tornar 
um canal para outras identidades - uma qualidade que, para Hamburger, era um atributo do tradutor. Dessa forma, não podendo haver um método, minhas preocupações, paralelas a meu trabalho, dizem respeito a definir operações a fim de assegurar uma "latitude" para minhas paráfrases. Tentarei descrever apenas umas poucas, embora me pareçam adequadas à descrição de um sem-números de casos. ${ }^{12}$ Antes dessa descrição sumária, porém, convém deixar patentes alguns pontos de vista pessoais sobre as categorias de Dryden, a partir das quais venho tentando definir minhas operação para a conservação de "latitudes". ${ }^{13}$

Segundo sua classificação, sabemos que não podemos chegar, por meio de metáfrases, a um texto poético. A limitação mais óbvia da metáfrase é que, enquanto permite a apreensão do significado do original percebido pelo tradutor, ela não faculta ao leitor nenhuma percepção da estrutura ou técnica desse original. Por sua vez, na "imitação", é de supor, vamos além de uma "tradução". Deixamos uma tradução com "latitude" em favor do que se poderia dizer uma "tradução com atitude", essa se relacionando mais com o tradutor do que com o traduzido. De modo que quer-me parecer que o espaço da "criatividade" de uma tradução se encontra na paráfrase, caracterizada pelo que Dryden chama de "latitudes". Falar sobre as paráfrases que tento fazer equivale, pois, a falar dos modos pelos quais não sigo as palavras do autor tão estritamente quanto os sentidos que posso divisar nelas. ${ }^{14}$ Por isso, devo tentar descrever minimamente modos de operação.

Essas maneiras podem admitir, por exemplo, mudanças nas categorias gramaticais das palavras nas frases, comparativamente às do original. Assim, quem traduzisse o verso citado de Spender, "Arrowing to that sea" [arremessando-a àquele mar] por "arremessando-a ao mar além" de meu ponto de vista estaria fazendo uma paráfrase, a ideia de distância do demonstrativo sendo traduzida por um advérbio. ${ }^{15}$

Em paráfrases minhas e de outros, observo ao menos uma mudança admitida de uma figura de linguagem em outra - a de comparações que se tornam metáforas. O verso de Spender citado aqui, "The word bites like a fish", ao ser transposto para o português, tem seu símile transformado numa metáfora ("Palavra é peixe e belisca"). Tais mudanças sempre dependerão de uma análise de seu contexto, mas, nesse caso, suponho que o procedimento seja justificado comumente pela opinião de que uma metáfora tende a ser mais "eficaz" poeticamente do que uma comparação.

Comparativamente ao original, paráfrases podem envolver mudanças na ordem das palavras nas frases; eventuais alterações da ordem dos versos; sentidos detectados num verso e traduzidos em outro. Mas os modos de "não seguir as palavras tão estritamente" incluem outro aspecto mencionado por Dryden, para quem o sentido pode ser "ampliado, não suprimido"16 na paráfrase. A meu ver, essa dilatação do sentido diz respeito a nuanças inevitáveis que se podem acrescentar à tradução na passagem de uma língua para a outra. Traduzindo poemas, 
essa é uma grande preocupação para mim, e admito dois tipos de acréscimos semânticos em condições ideais - aqueles que 1) derivam de novos valores poéticos das palavras de nossa língua, gerados no contexto dado pelo original e em geral percebidos pelo tradutor durante o processo de escrita, sendo conservados na tradução como "achados poéticos"; e 2) derivam de sentidos implícitos que um tradutor pode detectar num original e utilizar em geral por necessidade de equivalência a estruturas do original, como metro e rima, por exemplo.

No poema “Old fools" ["Os velhos tontos"] de Philip Larkin, quando traduzi a expressão "rising ground" [subir o terreno] por "subir o morro", dei-me conta do acréscimo semântico de uma ambiguidade se formando, como se espontânea, na palavra "morro", tendo como sentido primário o "monte de pequena elevação" e, como secundário, o verbo "morrer" na primeira pessoa do presente do indicativo, em virtude de um contexto relacionado com velhice e morte, essa representada como um "pico" observado a distância por jovens, mas "escalada" por velhos: "[...] This must be what keeps them quiet:/ The peak that stays in view wherever we go/ For them is rising ground. [...] [“[...] Talvez seja isso o que os mantém serenos:/Em qualquer canto onde se esteja, o pico sempre à vista/ Para eles é subir o morro"]. Outro exemplo de que me lembro se acha em Vênus e Adônis, em que a escolha de "soltando ais" para traduzir "whereat it groans" ["com o que ele solta lamentos"] acabou por gerar um eco no interior do verso, em conformidade com um contexto de "ecos", a palavra inglesa "verbal" à época se ligando exclusivamente a palavras, não a sons naturais: "And now she beats her heart, whereat it groans, / That all the neighbour caves, as seeming troubled, /Make verbal repetition of her moans; /Passion on passion deeply is redoubled" ["Ora golpeia o peito, soltando ais,/ E as caves perto, como se abaladas,/Fazem dos ais repetições verbais;/Lamúrias gravemente redobradas”].

A fim de buscar uma equivalência a alguma estrutura do original, só admito acréscimos semânticos que possam ser inferidos da análise do texto original. Por exemplo, no dístico seguinte, também de Vênus e Adônis, "For lovers say, the heart hath treble wrong/ When it is barred the aidance of the tongue" $17 \mathrm{O}$ acréscimo de "à mingua", é uma dedução da condição de carência da alma sem o refrigério das palavras ("língua") do ser amado: "Que amantes dizem, a alma sofre à míngua,/ Três vezes mais, se não lhe acode a língua”.

Quando depreendido da lógica do texto, esse tipo de acréscimo semântico me parece bastante "neutro", e tenho a impressão de ter recorrido ao expediente inúmeras vezes em meu trabalho, além de ter-me deparado com ele em versões de outros tradutores.

Nos estudos literários, a noção da condição ideal da "impessoalidade" por parte de um escritor ou narrador diz respeito, grosso modo, à sua não adesão a um código moral definido, e se tornou um valor literário esposado por escritores na época moderna, com suas suspeitas quanto ao eu psicológico e sua exacerbação no sentimentalismo, sobretudo após a crise do sujeito nos anos 1960 e 1970 . 
Acredito que, assim como se podem detectar expedientes literários que contribuem para a impressão de "impessoalidade", essas estratégias que mencionei, visando manter o "autor ao alcance dos olhos", contribuem para uma impressão, ou mesmo uma "ilusão", de "impessoalidade" da parte de um tradutor. Essa é, aliás, uma lição colhida no bom e velho Dryden, que, comentando suas próprias traduções, afirmou que "...where I have enlarged them, I desire the false critics would not always think, that those thoughts are wholly mine, but that either they are secretly in the poet, or may be fairly deduced from him" ["...quando as dilatei, desejo que os pretensos críticos nem sempre suponham que aqueles pensamentos são inteiramente meus, mas que ou se acham secretamente no poeta, ou podem ser justamente deduzidos dele"]. Uma metáfora que me parece apresentar notável analogia com essas operações, extraída do mundo da costura, me fascina: a do "cerzido invisível", um trabalho artesanal em que se retira um pequeno pedaço de tecido oculto na roupa para ser disposto, fio por fio, sobre o tecido ausente ou danificado, recobrindo-o. Em paráfrases, o tecido [textus] "oculto" são nossas deduções do texto, nos proporcionando as palavras e estruturas que, como os fios empregados na técnica, serão utilizadas na reconstituição do "padrão" percebido no original. Isso, claro, é diferente de "devorar antropofagicamente" um texto em outro idioma, o que, em termos de tradução, nunca me pareceu distante do que podia fazer a imitação de Dryden. Enquanto a imitação teve seu passado glorioso, e enquanto ela, ao ser capaz de nos deixar "arrepiados", torna ocioso perguntar "quem é o autor disso?", é a paráfrase que tende a predominar, talvez pela força das abordagens historicistas há muito em vigor nos estudos literários. E essa questão de novo parece levar ao aludido problema da nomenclatura, já que os mesmos críticos capazes de torcer o nariz às liberdades semânticas de uma "tradução", talvez pensassem mais antes de fazê-lo se a reconhecessem como uma "imitação", e talvez sua sensação não fosse, diante do que passa por uma "tradução", a de que a pessoa que a fez está "dando um presente" em vez de "pagar uma dívida", como disse Dryden. ${ }^{18}$

Não posso fazer paráfrases de um texto, claro, sem que tenha uma leitura dele, sem que tenha lido o máximo possível sobre ele e o tenha analisado. A natureza da tradução poética é dual e se materializa simultaneamente como leitura e escrita. Portanto, para tentar aclarar mais a tentativa de integração de uma coisa na outra no tipo de tradução poética que tenho em mente, gostaria de proceder a um breve comentário de um poema de Gerard Manley Hopkins, seguido de sua tradução, já que o espaço de um artigo não permite nenhum esforço crítico minimamente à altura da obra. ${ }^{19}$ Para tanto, será preciso apenas que o leitor saiba que meus comentários registram gestos poéticos, em termos de significado e significante, que julgo essenciais e tenho por objetivo traduzir. ${ }^{20}$ Em meio a esses comentários, cito minhas versões semânticas dos originais, que me servem de balizas para minhas paráfrases.

Mas eis o poema: 
Gerard Manley Hopkins (1844-1889).

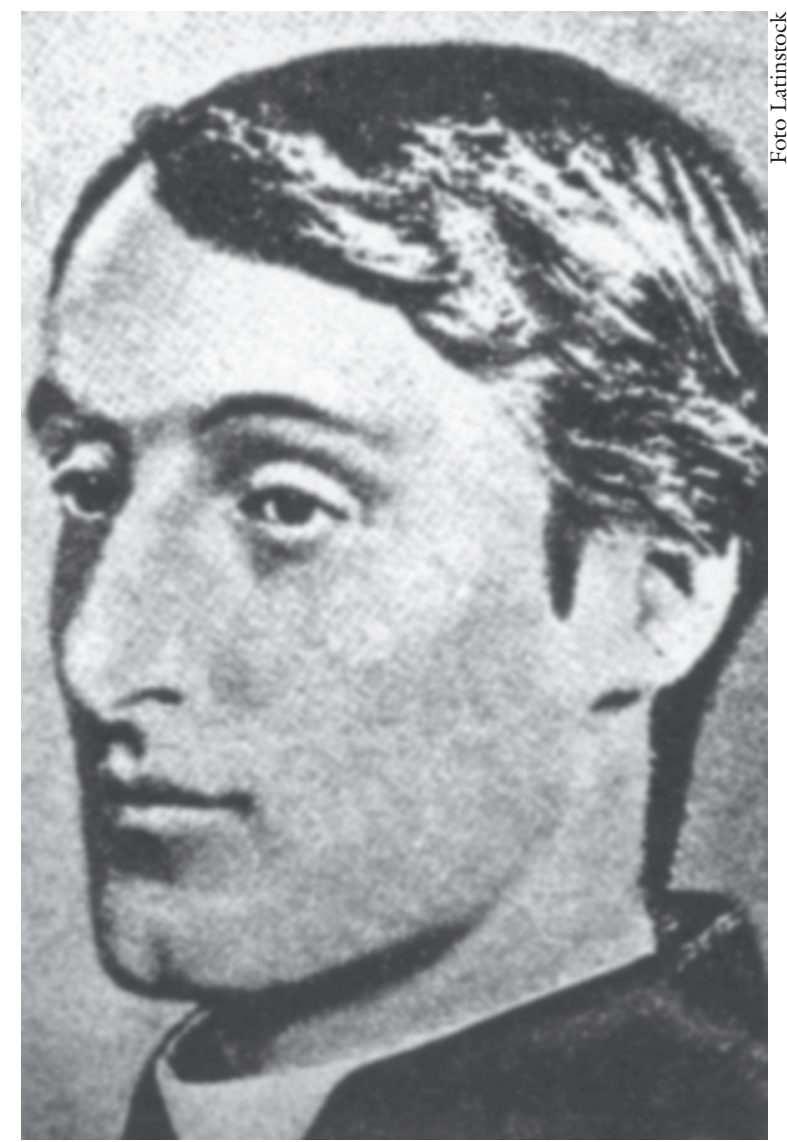

My own heart let me more have pity on; let

Me live to my sad self hereafter kind,

Charitable; not live this tormented mind

With this tormented mind tormenting yet.

I cast for comfort I can no more get

By groping round my comfortless, than blind

Eyes in their dark can day or thirst can find

Thirst's all-in-all in all a world of wet.

Soul, self; come, poor Jackself, I do advise

rou, jaded, let be; call off thoughts awhile

Elsewhere; leave comfort root-room; let joy size

At God knows when to God knows what; whose smile

's not wrung, see you; unforeseen times rather - as skies

Betweenpie mountains - lights a lovely mile.

Trata-se da composição que arremata os famosos "Sonetos da desolação", sua consequência lógica, de vez que nela vemos o poeta mais consciente sobre o egoísmo, ou covardia, que pode haver na introspeção excessiva, na ruminação torturante de seus próprios tormentos, ou então mais animado pela compaixão 
por si mesmo, pela aceitação da própria condição e da fé na misericórdia de Deus.

O primeiro verso leva a efeito, de maneira magistral, um expediente característico de Hopkins, marcado pela radicalidade - a violação da sintaxe e da gramática. Enquanto a ordem comum da frase seria "Let me have more pity on my own heart" ["Que eu tenha mais piedade de meu próprio coração"], a própria sintaxe do verso, por meio da posição enfática do complemento, é sugestiva de uma consciência dividida, em que “my own heart” simula ser a um só tempo o sujeito de uma apóstrofe e seu próprio objeto. A posição também insólita do advérbio de intensidade em "move have" é outro traço recorrente em seus poemas, e advém de uma percepção do grau ou medida como relacionados inextricavelmente à atividade expressa pelo verbo, o resultado parecendo soar como um verbo composto. O efeito estético disso é a impressão de um “caos vocabular”, em razão da sínquise, e sugestivo de uma mente que não consegue articular devidamente a frase: "Meu próprio coração que eu mais tenha piedade dele".

Consequência de um enjambement, o segundo verso faz o pronome "me" ["me"] se distinguir, como um outro eu, do "coração ["heart"] e de um outro "eu triste" [“sad self”] (aliterativo): “...que/ Eu viva para o meu triste eu a partir de agora de maneira gentil".

Nos terceiro e quarto versos, a "mente" ["mind"] se multiplica como uma série (com suas subsequentes aliterações), alternando a posição “atormentada" ["tormented"] e "atormentadora"["tormenting"] do sujeito e do objeto e assim configurando o círculo vicioso que se atormenta a si mesmo na ruminação: "Caridoso; não viva esta mente atormentada/ Com esta mente atormentada atormentando ainda”.

Considerando que o segundo quarteto do soneto terminará com imagens relativas a "um mundo de água" [ "a world of wet"], interpreto o sentido principal do verbo “cast" no quinto verso como se ligando a esse contexto: “deitar a linha”, como numa pesca. E o que é pescado, procurado aqui é o próprio “conforto", ou bem-estar (será preciso traduzir a aliteração em "cast for comfort"). Toda a estrofe, no entanto, é marcada por elipses dos pronomes relativos (o que é imperioso traduzir...], outro traço comum a Hopkins ("I cast for comfort, [which] I can no more find in my comfortless [world] than a blind man in his dark world can [get] day..." embora o "conforto" seja perseguido, o que o poeta acaba por "tatear" ("groping”) é um acidente sem definição substantiva, uma condição absoluta, já que é o próprio mundo que foi subtraído na elipse, uma condição expressa de forma magnífica por meio de um adjetivo substantivado - um adjunto, por assim dizer, pugnando por tornar-se sua própria definição. O mesmo processo é observado em "in their dark" ("em seu [mundo] escuro"), a condição dos "olhos cegos" ["blind eyes"] em sua busca do "dia", uma condição comparada. à do eu poético. Da mesma forma, em sua busca de paz, o eu poético também é comparado aos “sedentos” (a palavra 
"thirst" - em lugar de "thirsty" - do sétimo verso), incapazes de saciar sua sede em "todo um mundo de água", ao contrário, deparando com a "totalidade" da sede, a "essência da sede" ["thirst's all-in-all"] - uma outra condição absoluta-, numa imagem, aliás, com sua gênese provável na Balada de Coleridge ("Water, water every where,/ Nor any drop to drink") ["Água, água por todo lado/Sem nada que beber"] e simbólica de uma sede metafísica, os dois versos finais sendo marcados também por fortes aliterações: "Deito a linha ao conforto que eu não posso obter mais/ Ao tatear ao redor meu sem-conforto, do que cegos/ Olhos em seu escuro podem o dia ou os sedentos podem achar/A essência da sede em todo um mundo de água".

No nono verso, a fragmentação do eu-lírico continua a ser sugerida na conclamação de si mesmo por meio de nomes diferentes, "Soul ["alma"], self" ["eu"] e "Jackself", este último um neologismo combinando em sua órbita semântica noções do elisabetano "Jack" [ "joão-ninguém"] e outras expressões populares correlatas, como "Jack-of-all-trades" [alguém que, por se dedicar a muitas coisas, nada faz de maneira notável] - ou seja, expressões dando a ideia de uma pessoa modesta e laboriosa - como o jesuíta Hopkins. Esse mesmo sentido de caráter laborioso é enfatizado a seguir, na palavra "jaded" ["esfalfado"], com seu sabor coloquial e resultado da elipse de "who are" ["que está"]: "Alma, eu, vem, pobre joão-eu, eu aconselho/ A ti, esfalfado". A isso se seguem exortações piedosas a si mesmo, introduzindo um imaginário natural, por meio da palavra composta, e aliterativa, "root-room" [espaço para raiz] e do verbo "size" ["medrar"]": “...deixa estar; afasta os pensamentos por algum tempo/ Pra longe; deixa ao conforto espaço para a raiz; deixa a alegria medrar/ Deus sabe quando e Deus sabe em que proporção". No caso de "whose smile", eu o interpreto como se ligando à “joy" ["alegria”], não a Deus. ${ }^{21}$ Como não poderia deixar de ser, esse "sorriso" próprio da "alegria" "não é arrancado à força" ["s not wrung"]. O enjambement violento entre o décimo segundo e décimo terceiro versos (que requer "tradução") contrasta com a espontaneidade do sorriso. Por ser "da alegria", esse sorriso é capaz de alterar a percepção do mundo sensível, iluminando uma "adorável milha" ou trecho do caminho, em momentos tão imprevistos ["unforeseen times"] quanto aqueles em que a luz do sol dimana dos "céus" ["skies"]. "Betweenpie" é um neologismo [que precisa ser "traduzido", obviamente] resultando num verbo composto, formado pela preposição "between" [entre] e "pie", esta palavra advindo do adjetivo "pied" ["variegado"] mas sem uso reconhecido nesse sentido, qual seja, o de que os céus, vistos entre as montanhas, produzem um padrão variegado, ou mesmo de que a luz do sol, se derramando num vale, altera a cor das partes da montanha sobre as quais incide. No final do poema, a expectativa gerada após a exortação do eu poético a si mesmo de que observe ("see you") se resolve na evocação do caminho iluminado por meio das aliterações típicas de Hopkins: “...cujo sorriso/ Não é forçado, vê, tu; de preferência, em momentos imprevistos - quando os céus/ Produzem padrões variegados entre as montanhas - ilumina uma adorável milha”. 
São esses gestos poéticos que considero essenciais em minha leitura, e agora só posso esperar que o leitor os encontre na tradução, expressos de maneira mais "efetiva", como disse Hamburger, do que as palavras que acabei de usar:

Meu coração que eu mais me apiede dele; e brando

Eu viva ao meu eu triste desde este momento,

Caridoso; não viva a mente em seu tormento

À mente atormentada ainda atormentando.

Eu lanço a linha à paz sem poder ter, tateando

O meu sem paz, mais que o olho cego pode o alento

Do dia em seu sem luz, ou mais que alguém sedento

A sede toda em todo um mundo se inundando.

Alma, eu; vem, mísero joão-eu, ouve este aviso,

Ó, trapo; deixa, enxota um pouco estas idéias;

À paz terreno-a-raiz; cresça o ânimo feliz o

Quanto e quando Deus quiser; seu riso não é à

Força, vê: igual aos céus - que de improviso

Entrematizam montes - luz por linda aleia.

Notas

1 Não me refiro propriamente à não identificação com leituras em soluções, o que é tão entre adeptos do ofício, mas a expedientes, como interpolar textos de outros autores em traduções, a exemplo do que fizeram Augusto e Haroldo de Campos, seguindo a esteira de Odorico Mendes, para eles o "patriarca da tradução criativa" no Brasil, ou mesmo levar a efeito uma tradução cujo resultado seria um poema "mais difícil" do que o original, como foi a intenção de Décio Pignatari ao traduzir a "Ode à melancolia" de Keats.

2 Pound se referiu à sua tradução do "The seafarer", às presentes em Cathay e a sua "Homage to Sextus Propertius" como suas personae principais. Como título para a coletânea composta por duas antologias anteriores e publicada em 1919, ele escolheu Personae, um título que, de resto, seria usado mais duas vezes, uma, para os poemas reunidos e publicados em 1926, a outra, para uma seleção da edição de 1919, por sua vez lançada em 1928. O registro da importância que o poeta conferia à palavra pode ser encontrado em seu texto intitulado "Vorticism" ["O vorticismo"], publicado em 1929, em que ele chama seus poemas, bem como suas traduções, de simplesmente uma série de "máscaras elaboradas". Ou seja, desse ponto de vista, como viria a afirmar Hugh Kenner em seu estudo paradigmático sobre o autor, essas personae, para Pound, se constituíam em dramatizações deliberadas que ampliavam modos de pensamento e sentimento acessíveis ao habitante comum de uma dada época de Londres.

3 Como tradutor, Hamburger foi responsável por uma maior compreensão da literatura alemã no mundo inglês, acontecimento que curiosamente teve início em 1943, com suas aclamadas traduções de Hölderlin. Dentre os muitos escritores que traduziu extensivamente se acham Büchner, Göethe, Celan, Grass, Huchel, Hofmannsthal, Rilke 
e Trakl. Por esse trabalho, Hamburger recebeu diversos prêmios, dentre os quais a Medal of the Institute of Linguists, o Schlegel-Tieck Prize, Wilhelm-Heinse Prize Medallion, Goethe Medal, o European Translation Prize, Hölderlin Prize e o Petrarca Prize.

4 Tradutores que têm sido apontados como herdeiros da abordagem de Hamburger são Keith Bosley, Alistair Elliot, Harry Guest, Peter Jay, Anthony Rudolf, David Constantine e David Cram.

5 Incluo esses comentários de Hamburger, bem como um texto seu sobre Larkin e cedido a mim, em minha edição de 80 poemas de Philip Larkin, a ser lançada pela Ateliê.

6 Michel Hamburger, Testimonies: setlected shorter prose, 1950-1987, Londres: Carcanet, 1989 , p.259-60.

7 Diga-se também que as versões de Robert Lowell, tão controvertidas quanto as de Pound, receberam dele o nome de "imitações", reivindicando de maneira explícita sua condição de partícipe dessa linha.

8 Trata-se de uma questão de nomenclatura, mas ela determina uma atitude, ou abordagem, em face da atividade.

9 Minha versão semântica: “A palavra morde como um peixe. Devo lançá-la de volta, livre/ Arremessando-a àquele mar/ Onde os pensamentos agitam a cauda e a barbatana? Ou devo colocá-la/ Para rimar num prato?”.

10 Tendo a ver os acréscimos semânticos dessa versão (“... no final da/ Linha”) como que fazendo do verso uma "imitação", devido à ambiguidade da palavra "linha", inexistente no original, conjugando o sentido principal de "linha escrita", ou "verso" e o secundário, ditado pelo contexto, de "linha de pescar", o que cria outra analogia com "isca". Mesmo que a solução envolva ideias pertencentes ao campo semântico do poema ("bites”, “fish”) e ressalte a natureza metalinguística do original, é o peso dessa ambiguidade na economia de valores poéticos do poema que me faz pensar nesses versos como uma "apropriação".

11 Em seu ensaio paradigmático "A tradução como criação e como crítica", Haroldo de Campos toca na mesma questão: "Então, para nós, tradução de textos criativos será sempre recriação, ou criação paralela, autônoma porém recíproca. Quanto mais inçado de dificuldades esse texto, mais recriável, mais sedutor enquanto possibilidade aberta de recriação". Ele não se refere, claro, a "paráfrases", mas essas palavras me parecem trair a percepção subliminar da necessidade de "latitudes". Na verdade, ele chega a reconhecer um "parâmetro semântico": "O significado, o parâmetro semântico, será apenas e tão-somente a baliza demarcatória do lugar da empresa recriadora". Minha discordância quanto a essa alegação está no fato de Haroldo considerar esse parâmetro "apenas e tão-somente a baliza demarcatória". Não me parece "apenas e tão-somente", justamente por balizar a empreitada, e por ser um aspecto em virtude do qual um texto poderá ser considerado uma tradução ou uma apropriação. Suponho que a "criação" de um tradutor de poesia deve se dar nos limites determinados por esse parâmetro, e que a tradução da "fisicalidade" do signo linguístico deve fazer parte dessa "criação". A meu ver, parte do "prazer" que nos pode advir de uma tradução poética deriva de nossa impressão de êxito do tradutor em face do desafio de reconstituir um "padrão" no original dentro dos limites da esfera de atuação determinados pelo que podemos confirmar como latitudes.

12 Ao fazer isso, não tenho a pretensão de entender precisamente os processos envol- 
vidos, e admito a possibilidade de estar equivocado quanto a postular uma diferença absoluta entre minha abordagem e a vinculada à linha poundiana.

13 Reza sua célebre definição, que se encontra no prefácio de sua tradução das Epistulas de Ovídio: “Consta que há três tipos de tradução; primeiramente, há metáfrase, tradução de um autor palavra por palavra, e linha por linha, de uma língua para outra. [...] Em segundo lugar, há paráfrase, ou tradução com latitude, em que o autor é mantido ao alcance dos nossos olhos [...] porém suas palavras não são seguidas tão estritamente quanto seu sentido, que também pode ser ampliado, mas não alterado. [...] Há imitação, em que o tradutor (se é que já não perdeu esse nome) assume a liberdade não somente de variar as palavras e o sentido, mas de abandoná-las quando achar oportuno, retirando somente a idéia geral do original, atuando de maneira livre e a seu bel-prazer".

14 Um dos "reparos" à definição de Dryden adviria da pergunta "qual o sentido do texto"?

15 Evidentemente, os tipos de operação que mencionarei aqui podem ser observados num sem-número de versões de outros tradutores, mesmo que não pensem em termos de "paráfrases".

16 É preciso relativizar: a frase: o sentido percebido pelo tradutor.

17 Minha versão semântica: "Pois os amantes dizem, o coração sofre três vezes/ quando é privado do auxílio da língua".

18 Enquanto escrevia esse artigo, um texto anônimo publicado na revista Veja, divulgando um livro com versões póstumas que Haroldo de Campos fez de Kaváfis, se refere a "maneirismos e liberdades indevidas" nelas, justificando esse comentário com a menção ao que o autor das linhas considera uma "alusão engraçadinha a um verso famoso de Carlos Drummond de Andrade no final de 'À espera dos Bárbaros'”. Ao mesmo tempo, o mesmo autor reconhece a "compensação desses deslizes" por meio da "fluência de seu verso", da "riqueza de seu léxico"e da "originalidade de suas invenções linguísticas". Acredito que o sentimento de "ambivalência" expressos nessas palavras, independentemente de não serem uma avaliação crítica aprofundada, exemplifica a impressão comum a que acabo de me referir.

19 Limito-me aqui a destacar pontos-chave de minha leitura do poema, constantes de um livro que preparo e que incluirá um estudo crítico sobre Hopkins e 40 traduções de seus poemas.

20 Sou obrigado, também por questões de espaço, a me abster de comentar questões de ritmo, importantíssimas no caso de Hopkins - em particular, seu metro idiossincrático, denominado por ele de "sprung rhythm" ["ritmo saltado"] - e de oferecer propostas de reconstituição deles em português. Por outro lado, menos por espaço, e mais por costume, me abstenho de comentar duas traduções brasileiras publicadas antes da minha, de Aíla Gomes e Augusto de Campos. Acredito que, uma vez que um tradutor elabora sua leitura do original e a materializa em versos, é raro que seja possível a ele se distanciar dessa leitura a ponto aceitar sem reservas outras versões como alternativas. Acho que exprimo um sentimento geral entre adeptos do ofício ao afirmar que, se nos depararmos com uma tradução apresentando uma leitura do original capaz de preencher satisfatoriamente nossa "cota de prazer", talvez não nos sintamos instigados a traduzi-lo. No meu caso, não tive nenhuma identificação de leitura com essas traduções, e minha crença no caráter ocioso de as comentar deriva da 
opinião de que, se penso em termos de uma "crítica em versos", uma nova tradução será suficiente para patentear discordâncias de leitura.

21 Há divergências sobre isso entre os estudiosos, mas essa interpretação parece a mais convincente em termos de poeticidade.

RESUMO - Este artigo apresenta o depoimento de Alípio Correia de Franca Neto, autor de várias traduções poéticas para o português, acerca de sua experiência nessa área, desde sua influência inicial no que concerne às ideias de Ezra Pound, divulgadas no Brasil pelos poetas concretistas, até seu subsequente afastamento dessas ideias, em favor de uma prática tradutória baseada nas antigas concepções sobre "paráfrase", formuladas por John Dryden, e em nosso dias desenvolvidas em escritos críticos e na prática de tradução de poesia de Michael Hamburger. O artigo se encerra com uma análise de um poema de Gerard Manley Hopkins, acompanhado de sua versão poética.

PALAVRAS-CHAVE: Tradução poética, Paráfrase, Imitação, Ezra Pound, Michael Hamburger.

ABSTRACT - This article offers an appraisal by Alípio Correia de Franca Neto, author of several poetic translations into Portuguese, of his experiences in this area - from the early influence of the ideas of Ezra Pound, disseminated in Brazil by the concrete poets, to his subsequent retreat from those ideas in favor of translation procedures based on ancient concepts of "paraphrase", as formulated by John Dryden and developed in our days in the critical writings and the practices of translating poetry of Michael Hamburger. The article ends with an analysis of a poem by Gerard Manley Hopkins, alongside a poetic translation.

KEYWORDS: Poetic translation, Paraphrase, Imitation, Ezra Pound, Michael Hamburger.

Alípio Correia de Franca Neto é tradutor e pós-doutorando em Teoria da Tradução. Dentre suas traduções, se destacam: A verdade da poesia, de Michael Hamburger (CosacNaify); Sete tipos de ambiguidade, de William Empson (a ser lançado pela CosacNaify); Música de Câmara, Pomas, um tostão cada (Prêmio Jabuti de tradução em 2001) e Exilados, de James Joyce (Iluminuras); O flautista de manto malhado em Hamelin, de Robert Browning (Iluminuras); Marco, o barco, de Ted Hughes (Prêmio Fundação Nacional do Livro Infantojuvenil na categoria Poesia em 2011; CosacNaify); A balada do velho marinheiro, de S. T. Coleridge (Prêmio Jabuti de tradução de 2005; Ateliê); Vênus e Adônis, de William Shakespeare (a ser lançado pela Leya); 80 poemas de Philip Larkin (a ser lançado pela Ateliê); Inmagens: 40 poemas de Gerard Manley Hopkins (a ser lançado pela Ateliê); e Um dia de dândi, tradução em parceria com Elena Vássina do primeiro capítulo de Evgéni Oniéguin, de Aleksandr Púchkin (a ser publicada pela Ateliê). @-alipiofranca@ig.com.br

Recebido em 17.9.2012 e aceito em 27.9.2012. 
